\title{
Metaphors of Interrelatedness in Lorna Crozier's Small Beneath the Sky: A Prairie Memoir
}

This article focuses on metaphoric structures in Lorna Crozier's Small Beneath the Sky: A Prairie Memoir (2009). Crozier's straightforward narrative of incidents from her past is structured around a series of poetic vignettes describing originary phenomena that have shaped her. The "first causes," as she calls them metaphorically, add up to the familiar mix of parameters of origin and belonging: the intimate place/landscape, family, and discourse. My aim is to demonstrate how Crozier's metaphors contribute to the world of interrelatedness she constructs in the memoir. In the process, Crozier continues to develop a broader project of the revisioning of patriarchal mythologies (e.g., the Canadian myth of the prairie West) from a female/feminist point of view. ${ }^{1}$

In an interview, Lorna Crozier - a recognized Canadian poet - states that the 2009 "prairie memoir" of her Saskatchewan childhood and much more selectively treated adulthood titled Small Beneath the Sky is "a life work for me. [...] it's about questions and concerns I've been living with since I became conscious of my thoughts." Indeed, the themes, motives, and tropes she develops in the memoir are well known to the readers of her poetry, which often either tends towards the autobiographical or is openly so. The memoir itself, Crozier's first attempt at prose writing, in fact hovers between poetry and prose both in terms of style and form. The mosaic-like sequence consists of the straightforward narrative of incidents from Crozier's past - some of which include moments of epiphany - described in brief prose chapters punctuated by vignettes in poetic prose, which can also be read as prose poems. The vignettes constitute attempts at capturing the originary phenomena that have shaped the autobiographical narrator, and which she metaphorically calls "first causes." The "first causes," which Crozier, inspired by Aristotle, describes as "something beyond the chain of

1 Research for this article was supported by the National Science Centre Poland under grant PRO-2012/05/B/HS2/04004.

2 Susan Olding, “An Interview with Lorna Crozier - Featuring New Work!” <http://susanolding. com/an-interview-with-lorna-crozier-featuring-new-work/> (acc. 10 June 2017). 
cause and effect, something that started it all,"3 are light, dust, wind; mom and dad; rain, snow, sky; insects; grass, gravel, horizon; story. They add up to the familiar mix of parameters of origin and belonging to which they are synecdochically related: place, family, and discourse.

Juxtaposing prose sketches of fleeting snatches of the past and poetic vignettes of what might seem transient or incidental, but nevertheless endures, produces a sense of a deep and intimate connection between the two "orders." The end result, as was Crozier's intention, ${ }^{4}$ is a verbal moving picture of herself and her other human subjects engaged in the hustle and bustle of life set against a timeless, almost mythical, though hardly stationary or inanimate background, with which they are intimately connected. In this respect, the memoir is continuous with Crozier's poetic project: the contention she develops in her poems that sentience is not just a quality of people, but rather of everything that surrounds us, animals, the natural world, the inanimate world, the universe itself, ${ }^{5}$ and her delight in the ordinary and mundane, in what we overlook in everyday life. ${ }^{6}$

My aim is to demonstrate how Crozier's specific rendition of her conceptual metaphors - "place/family/discourse is a beginning/the point of origin," i.e. the textual rendition of the entities metaphorized as her "first cause" - contributes to the world of interrelatedness she unobtrusively constructs in the memoir. The "self" that the text describes is deeply relational" and formed by interactions with others and the stories they tell, but - even more crucially - this self is given rise to, is shaped and sustained by the natural phenomena of the prairies, which become "the pared-down language of your blood and bones" (SBS, 194) and are actualized through "story." The sense of relationality and of the inextricable interrelatedness of discourse, material/natural world and the self that the text gives rise to is constructed and supported primarily by means of an intricate web of intersecting metaphors. In the process, the memoir becomes yet another contribution to a broader project of Crozier's writing often remarked

3 Lorna Crozier, Small Beneath the Sky: A Prairie Memoir (Vancouver et al.: Greystone Books, 2009): n. pag.; further references in the text abbreviated as "SBS".

4 Olding, "An Interview."

5 Marilyn Rose, “ 'Bones Made of Light': Nature in the Poetry of Lorna Crozier," Canadian Poetry 55 (2004): 56-58. <http://www.canadianpoetry.ca/cpjrn/vol55/rose.htm> (acc. 10 December 2016).

6 Shelley Boyd, Garden Plots: Canadian Women Writers and Their Literary Gardens (Montreal: MQUP, 2013): eBook Collection (EBSCOhost).

7 Cf. Paul John Eakin, How Our Lives Become Stories: Making Selves (Ithaca and London: Cornell UP, 1999). 
upon by critics: a revalidation of the feminine and a re-visioning of patriarchal mythologies, ${ }^{8}$ in particular the Canadian myth of the prairie West, from a female/feminist point of view. These aims are partly achieved through a redefinition of the relationship between human beings and nature. ${ }^{9}$ In the memoir, however, they are accomplished, to a large extent, through subtle foregrounding and the universalizing of the figure of Crozier's mother, written into the landscape of the prairies, but also through the way in which Crozier conceptualizes her own self.

The way Crozier describes the first causes makes it clear that she does not really differentiate between animate and inanimate, tangible and intangible; a phenomenon, a place, a plant, an insect, a person, a story. All are primary and crucial; all are both "hers" and "everybody's." While the poetic vignettes, in contrast to the prose pieces, use the second and not the first person perspective, as well as present tense, rather than past, in order to achieve a sense of distance and of permanence of the "first causes," they nevertheless rely on descriptions that foreground lived, sensual, specific bodily experiences. This, again, is particularly important in the case of those "causes" that are features of place, and which collectively build the image not of the town of Swift Current in Saskatchewan - Crozier's home town, which is described in the prose fragments and the farms close to it, but of the prairie environment (Saskatchewan and Canadian prairies) in general. In fact, place is the "first cause" par excellence to which all of the pluralized "first causes" of Crozier's memoir are related in one way or another. Even "mom and dad" and "story" are part of place: the former belong in it, the latter originates from it and makes it, by providing the autobiographical self access to place not only in the present, but also in its past incarnations remembered not through her own stories, but through stories of others.

Crozier's foregrounding of place is not surprising, given her grounding in Canadian literary tradition (which will be addressed later in this text) and given the importance of place in the process of remembering, and its presence in the common everyday metaphors. The metaphors - often utilized in self-texts transform the temporal into spatial and conceptualize our lives in terms of space or movement in space (suggesting, for example, that life is a journey, that it can be mapped, that the past is back or behind you and the future ahead of you, etc.). The past is always placed "in actual experiences of remembering, the spatiality and temporality of the mnemonic presentation are often correlated to the

8 Boyd, Garden Plots, eBook Collection (EBSCOhost).

9 Cf., for example, Rose, “'Bones Made of Light.” 
point of becoming indissociable."10 The key to the past, if we follow Edward S. Casey's argument, is "place" in the sense of space as experienced, lived, endowed with emotion; place "which cannot be reduced to site (the just where) [...] Having been places is [...] a natural resource for remembering our own being in the world."11 In her transformation of "actual experiences of remembering" into a well-crafted memoir, Crozier transforms the temporal into spatial experienced and re-experienced, so that her text seems to metaphorically invoke space, not simply and not only as a container of both the body itself and lived experience, but as place so strongly linked to the autobiographical subject that it not only defines it, but makes it. Similarly, place depends on the subject for its existence. As Deirdre Heddon notes, analyzing various approaches to the concept, place has no objective existence beyond the human subject; rather, it is "something we bring into existence thorough our relationships with it and our relationships with others in, on or around it." ${ }^{12}$ Remembered places depend for their existence on our experience of place. The way Crozier presents remembered place as experienced through the senses and the body seems to confirm Casey's contention that "an intimate relationship between memory and place is realized [...] through the lived body [...] the lived body puts us in touch with the psychical aspects of remembering and the physical features of place."13

Even though in her descriptions of the "first causes" Crozier strives for the sense of the mythical and unchanging, they are rooted in intimate, sensory, bodily experience, which she universalizes and makes atemporal through the use of the second person as her primary narrative perspective in the vignettes. The pronoun "you" is, on the one hand, often used in very specific contexts, so that it is clear that it refers to the lived experience or facts from the life of the autobiographical narrator - strengthening, however, the sense of both temporal and, we might assume, spatial distance of the narrator from phenomena or events described. On the other hand, the "you" promises to include readers, regardless of their individual backgrounds or experiences, paradoxically reducing the distance between them and the phenomena or events, suggesting a universal, even mythical, nature of what is described, inviting readers to look both into and beyond the incidence of individual life. This is well demonstrated in the three opening vignettes of the memoir. In the first one - "first cause: light" -

10 Edward S. Casey, Remembering: A Phenomenological Study (Bloomington and Indianapolis: Indiana UP): 71.

11 Casey, Remembering, 215 (emphasis in the original).

12 Deirdre Heddon, Autobiography and Performance: Performing Selves (New York: Palgrave Macmillan, 2008): 93.

13 Casey, Remembering, 190 (emphasis in the original). 
Crozier metaphorically describes "light" as experienced in "the plains where you were born," as "another form of water." She develops the metaphor to transform the visual into tactile experience: the light is palpable, can be touched leaving the skin damp, "after an hour or two of walking, you are soaked in brightness," its currents can drown you. At the same time, it feels animate, its dampness reminding "you" of a dog licking your cheek, its quality - of a bird: "All day long it touches you with the smallest of its million watery wings" (SBS, 1). Light in the plains is in this section a full-body experience, and a quality of place is described primarily through the effect it has on the person "emplaced." Like the majority of other renditions of "first causes," the metaphoric description contributes simultaneously to building the readers' sense of the Canadian prairies as an atemporal "first cause," a sense of how the autobiographical subject experienced the place and the life in the prairies in general. Yet, it also invites the readers to "feel with" the narrator: to make a connection between specific descriptions and aspects of their own lived experience.

"Dust," as defined in the vignette that follows, is the opposite of light and opaque where the light is "clear." It is shown as part of everyday mundane experience of the prairie life and as a grand metaphor for the mysteries of death and life:

It thickens your spit, it tucks between your fingers and toes, it sifts through the shell of an egg. Here's dust in your eye and ashes to ashes. It is the bride's veil and the widow's, the skin between this world and the next.

At the end, there is a return to how dust is experienced through the body, as the image becomes olfactory: "It is the smell you love most, the one that means home to you, dust on the grass as it meets the first drops of summer rain" (SBS, 2).

"First cause: wind," the third of the opening vignettes, completes - but does not exhaust - the description of the broad environment of the prairies by introducing plant, animal and human life into the picture. Wind, metaphorized as "an exhalation" of huge lungs, is described through its tangible effect on and interaction with "what loves [it] in this spare land": the aspens, the tumbleweeds, the wheat, the badger, the wolverine, and finally, a woman. Though loved, it is a force to reckon and contend with. The vignette concludes with the figure of the woman walking against the wind, "bent into it, a flat country's Sisyphus, the wind rising." Though unnamed, which gives her a universal aura, the woman is clearly special - loving the wind which "most of her kind hate" $(S B S, 4)$ - again both a generalized everywoman and one special woman, 
who - as the memoir develops - is strongly associated with the figure of Crozier's autobiographical narrator's mother.

The first three vignettes describe the prairie phenomena that seem intangible yet enduring, permeating the place, making the environment through which "you" move. Their impact is ambivalent; they are all both enchanting and dangerous, originary and final at the same time. Descriptions of the place-related "first causes" that follow - rain, snow, sky, insects, grass, gravel, horizon only develop and deepen the cords struck in the first three. The fact that the vignette on "light" opens the memoir is not coincidental. Light, through its metaphoric rendition as water, is presented as the source and sustainer of life, but also its figurative end: "If you stay too long in the open, you could drown, its currents carrying you to its source, your body bobbing, then going under, your lungs full of lustre" $(S B S, 1)$. In her poems, in particular in the volumes Everything Arrives at the Light (1995) and (though differently) in Apocrypha of Light (2002), which contains her rewritings of biblical stories, Crozier has already established light as the presence that begins it all. Light precedes and makes God, who is but the shape the light needs to "move inside" in order to confront darkness/absence and make the world glow/be. ${ }^{14}$ It makes its appearance in many of her poems at liminal moments of birth and death, the two often invoked at the same time, as in: "I remember my own birth, / tumbling forward / toward the light the dying speak of." ${ }^{15}$ Light, as Rose concludes, functions in Crozier's texts as "a principle that informs the world and all that is in it, thereby offering us a mechanism by which we can read, write and sing the sentient universe."16

The universal sentience, discussed by Rose in relation to Crozier's poetry, is evoked in the memoir mostly in and through the poetic vignettes. While the sense of "the sentient universe" emerges from the combination of prose and poetic pieces, in the vignettes themselves it is clearer in the descriptions of inanimate phenomena or plants ("first cause: grass") than, for example, of insects, though those are also treated as one of the "first causes." The vignette on insects (flies, grasshoppers, dragonflies, miller moths, mosquitoes, ants) foregrounds their omnipresence and seemingly timeless existence - in this respect they are like light, dust, and wind. The fragments tend toward simple description, stressing the effect the presence of insects has on both farm life and individual life. Again, however, insects are presented as intimately connected with the circle

14 Lorna Crozier, "Apocrypha of Light," in Apocrypha of Light (Toronto: McClelland \& Stewart, 2002): 3

15 Lorna Crozier, "Who has seen neither birth nor death," in Everything Arrives at the Light (Toronto: McClelland \& Stewart, 1995): 13.

16 Rose, “'Bones Made of Light,” 57. 
of life, but also eternal: flies are "the ones who started it all" (SBS, 104), miller moths leave "across the wall and counterpane [...] a grimy smudge, dust with some oil in it, close to what we must become" (SBS, 106), ants incessantly "recreate the earth" (SBS, 107). In "first cause: gravel" sentience seems to be out of question: "there's no un-man-made, earthly thing more lifeless," "nothing so resists pathetic fallacies" as gravel, the narrator notes. And yet, she also notes its resistance, "its need-to-go" (SBS, 135), recognizing finally the ultimate unknowability of gravel arising from its absolute difference from the human subject. It is accorded the status of a first cause, because "it is commonplace, and everywhere a prairie road can go" (SBS, 135), omnipresent and timeless.

The descriptions of landscape- and weather-related first causes also demonstrate human life as affected by place - a universalized picture that is particularized in prose recollections. The vignettes show not only the mutual relationship between place and individual subject, but cumulatively also give the reader a broader sense of the experience of life in the prairies, including the prairie farm, which features only tangentially in the autobiographical prose chapters. Crozier's life as a child and teenager is lived primarily in the town of Swift Current. Her parents, both born on farms, are relatively poor working-class town people. She knows farm life from the recollections of her parents and from regular visits to her maternal grandparents' farm. It is, therefore, to a large extent thanks to the "first cause" fragments that the reader receives a broad picture of the prairie and a sense of the area as primarily agricultural. "First cause: rain," for example, is presented not only as the receiver of the autobiographical subjects moods, "a mynah bird calling its notes" (SBS, 57), but - because of its alternating scarcity and overabundance, as well as its life-giving and life- and crop-destroying force - also as "a malevolent mercy, keeping a farmer off the field for half a season; a hard baptism, dropping crystal pebbles on your skin, flattening the ripened crops, the most bountiful in twenty years," and a force that has the power to make "the people dance" (SBS, 57).

Setting her individual experience against the broader natural and cultural landscape of the prairies and a prairie town, Crozier enters a territory densely written over by Canadian historical, cultural and literary discourse. For a reader of Canadian literature, the dominant position she accords to light, dust, wind, rain, snow, sky; insects, grass, gravel, horizon, family and story are overly familiar. The harsh experience of prairie settlement, the stifling atmosphere of a small prairie town, the image of a prairie family, and finally, stories of the prairies and prairie homesteading in general have constituted an important part of Canadian national mythology. Canadian prairie literature - first through its romanticized renditions of the Canadian West as a paradise in the making and a laboratory of a new society, later in realistic revisions of this mythology in novels by Fred- 
erick Philip Grove, Robert Stead, Martha Ostenso, W. O. Mitchell and Sinclair Ross, and more recently through rewritings of the earlier paradigms by writers such as Aritha Van Herk or Margaret Sweatman - has not only contributed to the creation of this mythology, but also reflected and challenged it. In the second half of the nineteenth century and the first decades of the twentieth century, when Canada sought to draw immigrants to the prairies, the prairie settlement was conceptualized as a way of changing barren wasteland into a bountiful Eden, thereby constructing a new society guided by the values of the reinvigorated British Empire. S. Leigh Matthews comments:

That the Canadian West was intended to inspire a rebirth of the British Empire, together with all its perceived superior and 'civilized' values, inevitably meant that cultural narratives of western expansion and settlement became inscribed by a spatial politics of gender. $^{17}$

Culturally, and through the medium of literature as well as political propaganda, the process was presented as a primarily masculine heroic endeavor. The prairies themselves, the land conceptualized as clear of any prior history or signification, were presented as fertile and feminine, open to penetration, exploration, possession and cultivation by the male settler. The figure of the prairie woman was constructed in this discourse analogically as that of a sturdy, fertile helpmate of the settler. Additionally, she was to function as the civilizing force and guardian of moral values: "in the late-nineteenth and early twentieth centuries, the image of the white prairie woman was represented as the central vessel through which the Anglo ideology of 'civilization' would be replicated in the west." ${ }^{18}$ Canadian literature responded with images that variously supported or challenged the ideology.

While even early prairie novels demonstrate a variety of approaches, allowing for interpretations foregrounding a number of different motives and tropes, Canadian literary critics from the 1940s through the 1970s - Edward McCourt, Henry Kreisel, Eli Mandel, Laurie Ricou, Dick Harrison - chose to focus on what they perceived as a deterministic (though to different degrees) and rather dark relationship between landscape and character, and the alien and alienating

17 S. Leigh Matthews, Looking Back: Canadian Women's Prairie Memoirs and Intersections of Culture, History and Identity (Calgary: U of Calgary P, 2010): 210.

18 Matthews, Looking Back, 217. 
character of the prairie that resists articulation. ${ }^{19}$ The negative images of the hostile, but also flat and uninteresting natural environment of the prairies, the single-minded almost inarticulate male farmer and his hard-working, badly treated family, and of a parochial prairie town have dominated the cultural imagination in Canada. The images still persist in spite of the "rewriting" and critical re-reading of the prairie West in fiction and non-fiction as well as in works of literary criticism, history and culture from the beginning of the 1980s on. Perhaps the most important element of the more recent renditions of the prairie is the reassertion of the Native and female presence, and a changed presentation of prairie nature as neither the Eden nor the wilderness wasteland, but as a complex ecosystem that people are merely a part of. While life writing texts, especially memoirs by prairie women, have apparently always presented a less unequivocal image of the settlement and life on the prairies and the land itself ${ }^{20}$ than the one at least some of prairie fiction has, Crozier's reworking of the stereotypical images, especially the gender paradigm, is still unique. Nevertheless, the prairies she remembers and recollects remain staunchly Anglo-Saxon and devoid of Native presence. She only notes with regret that her grandfather had no stories about the first people; and that by her own times they were nowhere to be seen, ousted out of their ancestral grounds, their presence visible only through occasional artifacts found on the prairie. Similarly, her hometown, as she describes it, is a familiar, but stagnant little place, very much class- and genderconscious and prudish.

Crozier's memoir interestingly uses, confirms, and subverts some of the other established images and tropes. Apart from her nuanced presentation of the "first causes" that constitute familiar ingredients of the prairie environment, as discussed above, she manages to address also the gendered paradigms through which the prairies have been defined. Some of the recollections featured in the memoir seem to confirm at least part of the stereotypical image of prairie life and prairie family. Her maternal grandfather, for example, is a Welsh immigrant, who arrived in Canada with his family drawn by the false promises of free land, "healthful" climate, and agricultural plenty, only to discover after arrival that there was no more "free land left to homestead" (SBS, 25), and the land itself was bare and unwilling to yield harvest. In her rendition of the story, Crozier uses and subverts stereotypical images of the Canadian West exemplified by images shown by Canadian recruiters to the prospective immigrants, in which fertile

19 Cf. Alison Claire Calder, "The Lie of the Land: Regionalism, Environmental Determinism, and the Criticism of Canadian Prairie Writing," 1996. Digitized Theses. Paper 2670. <https://ir. lib.uwo.ca/digitizedtheses/2670/> (acc. 12 Nov. 2016).

20 Cf. Matthews, Looking Back. 
land willingly yielding its plenty to the farmer was feminized and personified as "blonde, Nordic-looking women bearing apples, grapes and huge vegetables" $(S B S, 26)$. Crozier offers a different personification and, alluding to the "Nordic-looking women," shows the story of her grandfather's life as played out under the "unrelenting" blue of the eye of the prairie sky: "a hard, no-nonsense colour impossible to romanticize. There was no way to match its gaze or change its mind" (SBS, 26). After many years as a hired laborer, Grandpa Ford manages to get a farm, but years of hard work make him a dour, unsmiling and cruel man, a tyrant to his wife and children, cruel to animals, hostile to formal education. The imagery Crozier uses to describe relations between her grandparents is the one famously summed up by Robert Kroetsch in his 1978 essay "The Fear of Women in Prairie Fiction" as the "horse : house" dichotomy, which he perceived as a baseline for gender relations in prairie fiction. ${ }^{21}$ Having associated man with open exterior spaces (and therefore with "horse") and woman with closed interior spaces ("house"), Kroetsch proceeds to build analogous pairs of opposites: "movement : stasis" and "pleasure : duty." In Crozier's memoir horses are definitely an attribute of the prairie man, used not only for work, but also for show during town parades, when pride of place is accorded to local big shots on horseback and a "life-sized black-and-white pinto made of steel" (SBS, 5). Gender relations on the prairie farm are definitely described as those defined by the "horse : house" dichotomy. The chapter titled "the drunken horse" starts with the description of her stern and sour Grandpa Ford's favorite story focusing on his loving relationship with his horse Billy, whose qualities - "endurance and willingness to work" - he shares (SBS, 28) and with whom he visits local pubs. Billy is the only animal treated by the grandfather with affection. When they get to the pub, Billy sticks his head through a window to drink the first pint of beer bought by the grandfather, and the delighted patrons keep buying drinks to the pair late into the night. The story brings together masculinity/horse/movement/ pleasure, a depiction which stands in stark opposition to the image of the maternal grandmother, always in the house, always busy, and alert not to be late to open the gate when her husband arrives "with his team of horses" (SBS, 27). Similarly, Crozier's paternal grandmother is associated with house/stasis/duty. After leaving the farm to her younger son, disinheriting Crozier's father in the process, she resides "in the smallest house [her granddaughter has] ever seen," incapacitated by her "milk leg," almost completely stationary. Both the grandfather and the

21 Robert Kroetsch, "The Fear of Women in Prairie Fiction: An Erotics of Space," in Sinclair Ross's As for Me and My House: Five Decades of Criticism, ed. David Stouck (Toronto: U of Toronto P, 1991): 114. 
grandmothers are presented as essentially unloving and cold, and unjust in the treatment of at least some of their children. Their relation to the land is based on hard relentless work and that to animals and family members on functionality bordering on cold pragmatism.

The stereotyped image of gender relations and prairie people is evoked in the memoir mostly in reference to the older generation of Crozier's family, the farm people, but also through images of big family celebrations, like Thanksgiving dinners on the farm, during which male and female duties were strictly defined and separate. However, descriptions of her parents, especially her mother, build a different image of prairie (town) people and their relation to their surroundings, though prairie town is not idealized, and remains a stifling, constricting environment. Nevertheless, Crozier's mother - though still focusing on household duties and child rearing - enjoys much more freedom than her mother did. While she works hard in the house and cultivating her garden, she - like her husband - takes up different jobs outside the house, enjoys curling matches and meetings with friends. Her daughter's duty is to be happy; there is no backbreaking work for the child, though helping around the house and in the garden is required. Crozier's father is an important, sometimes flamboyant, though murky presence in the text. His alcoholism, which the mother attempts to hide from the community, and his emotional detachment from the kids cast a shadow over the narrator's childhood and teenage years, thereby becoming a constriction and a lens through which young Crozier is perceived by others: "I was Emerson Crozier's daughter. That was the circle of light I stood inside no matter what I did or who I tried to be" (SBS, 97). This bitter but at the same time strangely warm image returns later in the memoir when, during dancing lessons with her father, she finds, to her surprise, a pleasure "in being inside the circle of his arms" (SBS, 123). It is the mother, however, who dominates every aspect of the memoir. In spite of poverty and her husband's alcoholism, she remains a sustaining presence, a nurturer devoted to her family, but also a provider and her own person, fully in control of her life, definitely not a victim trapped by economy and an unhappy marriage. Crozier's autobiographical narrator discovers the latter, to her shock, through the final words her mother directs to her husband, after scattering his ashes: "There you go, Emerson [...] You made my life better" (SBS, 150). It is also through those words that the narrator gets to recognize the mystery and the power of intimate long-term relationships; and it is through the figure of the mother that the reader gets a sense of a different, deeper nature of the relationship between people and the land, one not based on domination, exploitation and economic gain, but on love, or at least a sense of affinity.

When, in "first causes: mom and dad," Crozier announces that "[her mother's] favorite place is Saskatchewan: she can't understand why anyone would 
want to go anywhere else, even for a holiday, even in winter" (SBS, 34), the announcement simply concretizes the image the reader is already familiar with because, early in the text, in "first cause: wind," Crozier introduces the figure of the woman who loves the wind. She shows her out in the open (exterior) space, which is culturally coded as "male," enjoying her encounter with the wind. The description foregrounds the fact that "love," in this case, does not involve submitting to the force of the wind or enjoying its delicate caress. Rather much like Peggy Crozier's love for her husband Emerson and her family - it involves an unending, perhaps futile struggle ( $S B S, 4)$. The description foregrounds the determination and physical strength of the woman "pushing the boulder of the wind with her shoulders and chest," but also her affinity with the wind, whose energy is her own: "There's an energy that gusts inside her; wind steals her soul, adds distance and desire, then gives it back" (SBS, 4). Instead of a towering presence of the "vertical" man against the background of the "horizontal world," whose challenge he has to meet - as popularized by prairie realism in fiction and foregrounded by critics, notably Laurie Ricou - and instead of Kroetsch's man/horse/movement/pleasure - the first image of a human being Crozier's reader encounters is that of a woman leaning lovingly and forcefully into the wind: woman/movement/pleasure.

When an upright human figure in the flat landscape appears in the memoir, it is that of Crozier's autobiographical narrator - another female figure - next to a solitary tree $(S B S, 103)$. No struggle or attempt at dominating the landscape ensues. The tree, like some other natural phenomena and creatures appearing in the memoir - the stars, the snake - is transformed into a symbol of bitter knowledge and existential fear that comes with growing up. The cottonwood, the only tree in the vicinity of the town of Swift Current, Saskatchewan that was not planted by people, first appears in the text as a local landmark, not just a good place for picnics, but also a symbol of placedness and a safe haven. Recalling the time she spent under the tree with her friend Linda, sheltered by the leaves and branches from the outside world, Crozier's narrator says: "beneath the golden branches, we knew exactly where we were. Then, we didn't know how rare that was or what it meant. We didn't know how easily you can get lost once you move away from childhood" (SBS, 102). The realization comes later, when she drives to see the tree in winter, against the darkening sky. "Ordinary yet remarkable, the two of us were the only upright things for miles" ( $S B S$, 103), she comments. The leafless tree no longer "talks"; rather, Crozier writes, "its branches bore the blue star-silence of the snow" $(S B S, 103)$. The image, foregrounding the loneliness, the impending darkness, silence, coldness, alludes to two earlier moments of epiphany: one, when young Crozier, forced to watch boys nail a snake to a telephone pole, loses her fear of snakes and sees them instead 
as creatures gesturing at, able to taste with their tongues, "the darkness at the heart of things" (SBS, 73); and another one, when she "really" sees the stars for the first time - their cold, remote stare - and starts fearing the dark, feeling eternal loneliness. She writes:

That night, I knew there was no comfort in the world. Something pitiless among the stars had shown itself and seemed to know me. Among a thousand earthly things, it had picked me out for loneliness [...]. I knew then that was what waited in the dark [...]. (SBS, 81)

The transformation of the metaphoric meaning of the tree, from safe "home place" to a marker of cosmic loneliness, indicates the general trajectory of the memoir, which culminates with the long description of Crozier's mother's last days and the magic realist sequence of their two meetings and conversations when she is already dead.

The impending death of the mother makes the autobiographical narrator articulate her hope for the possibility that death means the energy of the body is returning to energy that makes the world. Even though she finds this vision heartening, she desperately yearns for her mother to remain "intact" after death, to watch over her, to remain a presence in her life. Her vision of immortality, however, adds a new dimension to the meaning of the first causes as participants "of the great mass of energy that makes up the world, its spirit and its matter" (SBS, 175-176). They are sustained by the same energy that sustains every individual human being. In a sense, then, they are us, we are them. Crozier reflects that her parents, who wanted their ashes to be scattered near the neighboring farms where they grew up, close to a stream emptying into an alkaline lake, will return to the element from which they were made and were a part of, the prairie: "the minerals leaching into the food and water that nourished them came from the same dry wheatland soil. [...] Their eyes filled with the unblinking prairie light that candled the stubble at dawn" (SBS, 149-150). The two appearances of the mother during her writer's retreat in a monastery not far from Saskatoon - first on the bleachers, then in a wheat field - might be read as an imaginative response to the desire to keep the mother as she was in life: in her bodily form, separate from the prairie. However, it might also be read as an expression of the hope that the dead somehow endure and can be recaptured through the world that surrounds us - an interpretation supported by the fact that while the memoir describes the months of the mother's final decline and her approaching death, the author does not give the description of the mother actually dying. Mom, one of the first causes, remains - like them - eternal. The strange transformation, or even destruction, of time that eternity implies is already hinted at as the family sit vigil at the house of the dying mother. 
The house becomes open to the elements, discrete units of time disappear, and time itself is revealed to be a curtain or a shroud: "wind blows through the hours and shreds them into ragged strips. There's no definite beginning or end to one hour, two, three" (SBS, 167). The shredded curtain of time refuses, however, to offer any glimpses into the "great beyond." The conversations Crozier has with her mother, as she makes her unexpected appearances, reveal no mysteries of existence, although, since they take place before Crozier is diagnosed with melanoma, the mother seems to be obliquely communicating a health warning. In general, however, the conversations are whimsical and focus on trivial matters. At the end, the mother disappears, leaving Crozier alone in a field of wheat - one of the stereotypical symbols of the prairie, the all-important place. The endurance, the omnipresence of the intertwining first causes is then perhaps the only "mystery" that the memoir posits.

The memoir finishes with the vignette titled "first cause: story," which brings together all the first causes, foregrounding the capacity of discourse to breach the bounds of time and space. Story and imagination give the autobiographical author access to times and events, and the family past she cannot possibly remember. Story is really the first cause and the last stand, it enlivens memory, which is not just individual but communal, "inherited." Story inheres in place, which is presented metaphorically as language:

This ache, this country of wind and dust and sky, is your starting point, the way you understand yourself, the place you return to when there's nowhere else to go. It is the pareddown language of your blood and bones. [...] Wherever you go, you speak with the earth on your tongue, in the accent passed down for generations. (SBS, 194)

The description denies the link Kroetsch makes in his essay between gender and discourse, his clean-cut division between male and female and his association of maleness with external space, which is "the silence that needs to speak or that needs to be spoken" and femaleness with the closed, interior space, "the having spoken," the book. ${ }^{22}$ For Crozier, the closed space of the house and the "having spoken" of the book are not identitarian points of reference; rather, she associates herself with the eternal language of the open prairie, a book without an ending. Even though she talks about the language as being handed down through generations, it seems that it is handed down most significantly in the female line - in the vignette her immediate ancestry is defined through her mother, which clearly associates the land and the language with femininity.

22 Kroetsch, "Fear of Women," 112. 
The device Crozier uses in Small Beneath the Sky of interspersing prose fragments with poetic vignettes of metaphorically rendered first causes allows her to construct a self and a world shaped by a dense network of interconnected forces and influences, those eternal and those incidental, among which discourse, story, is most basic and essential. The vision of old books with missing pages, which the narrator fills in with her own localized and individualized story $(S B S, 194)$, demonstrates metaphorically the process of asserting the importance and uniqueness of one's own life among many others by articulating it. 
